\title{
Construction OF A VACUUM Ultraviolet Transmission SPECTROMETER
}

\author{
Jiří Hlubuček ${ }^{1}$; Jiří Budasz ${ }^{2}$; Jan Václavík ${ }^{3}$; Karel Žídek ${ }^{4}$ \\ Institute of Plasma Physics, Academy of Sciences of the Czech Republic, \\ Regional Centre for Special Optics and Optoelectronic Systems (TOPTEC), \\ Za Slovankou 1782/3, 18200 Prague 8, Czech Republic \\ e-mail: ${ }^{1}$ hlubucek@ipp.cas.cz; ${ }^{2}$ budasz@ipp.cas.cz; ${ }^{3}$ vaclavik@ipp.cas.cz; ${ }^{4}$ zidek@ipp.cas.cz
}

\begin{abstract}
Measuring transmittance in the so-called vacuum ultraviolet (UV) region, namely between 160 and $190 \mathrm{~nm}$, is of interest for a range of materials (UV optical glasses and coatings, diamond, thin polymer films, etc.). However, both the necessity to carry out the measurement in vacuum and the need for specific UV-designed optical elements lead to the fact that the vacuum UV spectrometers are rather rare. Here we present construction of a home-made transmission vacuum UV spectrometer. It is based on a Seya-Namioka monochromator and enables us to determine transmittance of flat optical samples in the spectral range of $160 \mathrm{~nm}$ $600 \mathrm{~nm}$ with a spectral resolution below $2 \mathrm{~nm}$. We also outline future upgrade of the setup, which will highly improve its parameters.
\end{abstract}

\section{Keywords}

Ultraviolet spectrometer; Transmission spectrometer; Seya-Namioka monochromator.

\section{Introduction}

Transmission spectrum of a material or a sample carries immense amount of information about the studied specimen. In the case of thin films, the transmission curve can be used to extract the film thickness [1]. It can also provide information about concentration of a substance, or even reveal microscopic properties of the measured material (e.g. size of quantum dots) [2,3]. For this reason, a transmission spectroscope counts among basic pieces of equipment of spectroscopic laboratories.

A number of spectral features of interest are present in the ultraviolet (UV) part of spectra or even in the so-called vacuum UV (VUV) region with wavelengths below $190 \mathrm{~nm}$ [4-6]. This term is used due to the necessity to carry out the measurements in vacuum, since air very strongly absorbs the light in this spectral region. In addition, the VUV light needs to be emitted by a distinctive lamp and special imaging optics has to be used. Due to this fact, VUV transmission spectrometers, in spite of being a very useful spectroscopic tool, are rare.

\section{$1 \quad$ Research Objectives}

VUV spectral region covers wavelengths which are of interest for two main research applications: (i) development of UV optics for excimer lasers and photolithography [7, 8], (ii) material science (diamond, polymer thin films) [4-6]. Construction of a transmission spectrometer in this spectral range is indispensable for carrying out the research in the two topical directions.

In this article we present construction of such VUV spectrometer together with the testing measurements in the VUV region. The presented spectrometer can be used to carry out 
transmittance measurement in the 160-600 $\mathrm{nm}$ region and complement a broad range of spectometers available in the visible spectral region.

\section{Experimental Methods}

The transmission spectrometer is depicted in Fig. 1. It is based on the so-called Seya-Namioka monochromator construction, where the light source and exit slit are placed on the so-called Rowland circle [9]. The light source (Hamamatsu L7293 VUV lamp) is projected by a concave grating (Richardson Gratings) on a slit, which selects a wavelength for measurement. The selected wavelength is transmitted through a measured sample and refocused by an offaxis parabolic mirror (MgF2-coated Al mirror, Thorlabs) onto a scintillator (home-made, sodium salicylate layer). The light intensity is detected by using a photomultiplier (PMT) module Hamamatsu HC120.

The signal from the detector is read out via a DAQ card (National Instruments) and processed by a computer. The measured wavelength is scanned by rotating the concave grating via a motorized rotational stage (Thorlabs).

Source: Own

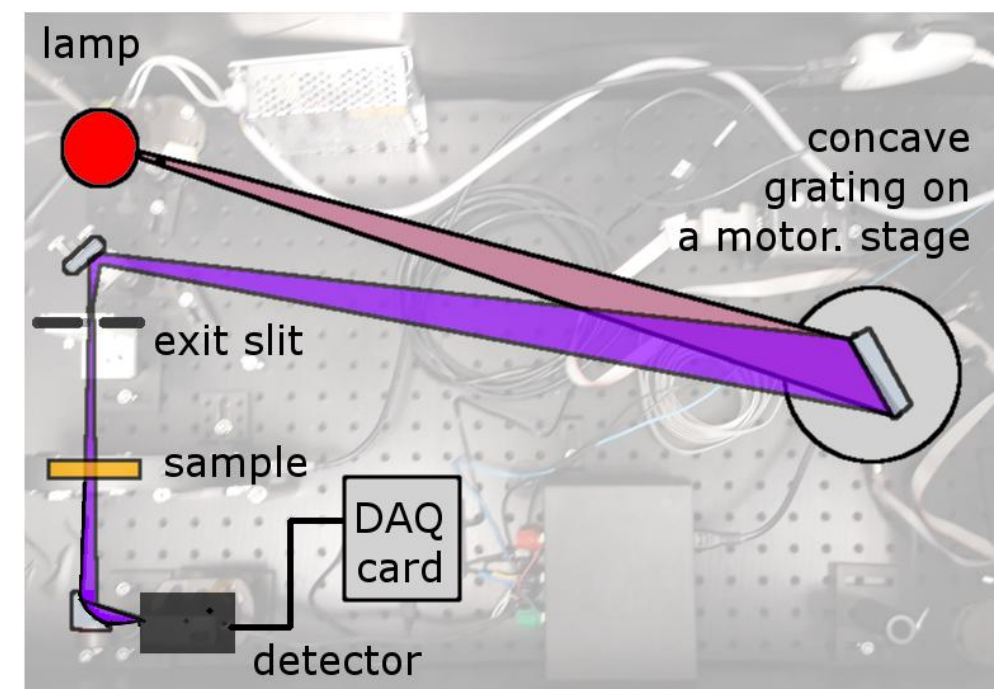

Fig. 1: Photo and an overlaid scheme of the UV spectrometer with removed covers of lamp, measurement and sample compartments

In order to carry out measurements in the VUV spectral region we enclosed the spectrometer in an aluminum box, which can be flushed with pure dry nitrogen and subsequently kept under a constant slight overpressure of the nitrogen inner atmosphere.

A 5-position filter-wheel is placed in the measurement spot and enables to measure background (blocked beam), full intensity (empty slot) and three samples. Future implementation of a separate mechanical shutter will extend the number of sample slots to four.

\section{$3 \quad$ Results and Discussion}

Firstly, we used a conventional spectrometer for wavelengths above $190 \mathrm{~nm}$ (Ocean Optics Flame) for the monochromator calibration (see Fig. 2). A "zero" position of the grating was found by searching for an intense zero-order peak (note that a decreased PMT gain has to be used in this case). Subsequently, the concave grating was rotated by small steps and for each step we recorded a spectrum of the light transmitted through the monochromator (see Fig. 2 inset). By rotating the concave grating we have tuned the wavelength from $190 \mathrm{~nm}$ to $650 \mathrm{~nm}$. 
The obtained calibration points can be well described by a third-order polynomial. Finally, it is worth stressing that the monochromator can be used for wavelength above $320 \mathrm{~nm}$ only after a proper color filter (e.g. N-WG320 Schott) is inserted, so that the second-order diffraction does not interfere with the measurements.

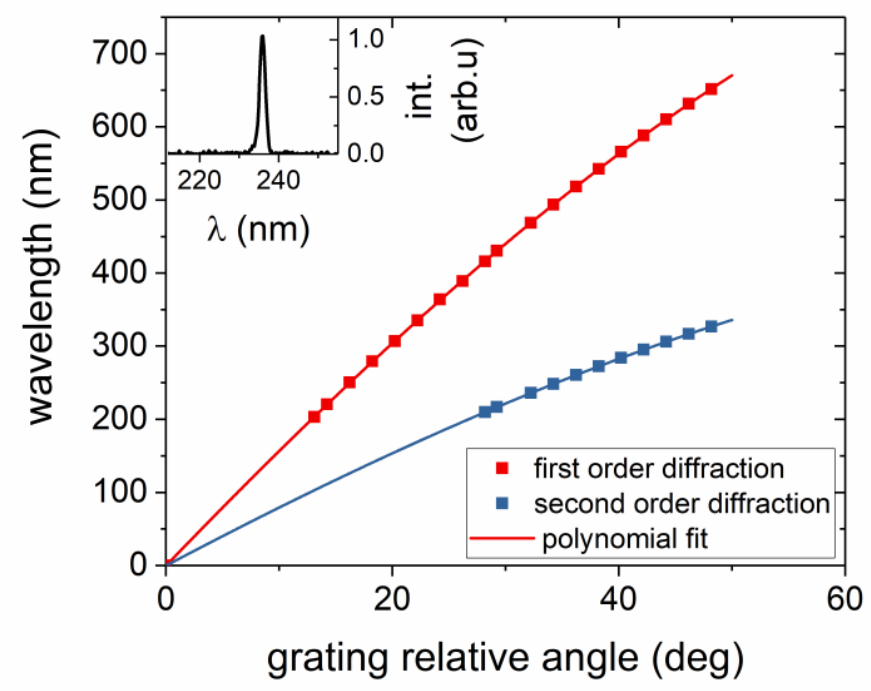

Source: Own

Fig. 2: Calibration curve of the UV spectrometer showing first- and second-order diffraction peaks (squares) fitted by a polynomial curve (solid lines). Inset: example of a measured spectrum with $1 \mathrm{~mm}$ exit slit. FWHM of the measured curves was used to determine resolution of the system.

The monochromator output was a narrow spectral line, which featured full-width in half maximum (FWHM) of $3.5 \mathrm{~nm}$ for $1 \mathrm{~mm}$ wide exit slit. This is in accordance with the granting spectral dispersion. Owing to a high sensitivity of the PMT photodetection, the spectral resolution of our experimental setup can be significantly improved by closing the exit slit. 

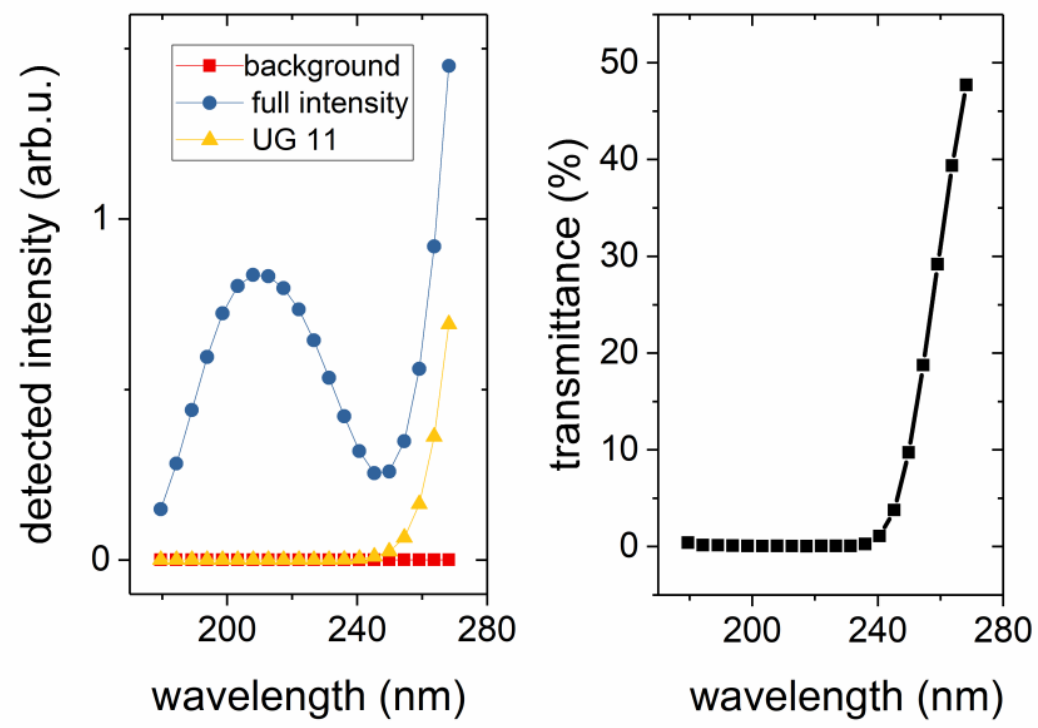

Source: Own

Fig. 3: Left panel: Example of measured background signal (squares), full-intensity spectrum (circles), and spectrum of light transmitted through a UG-11 Schott filter (triangles). Right panel: calculated transmittance by using the input data.

Transmittance $\mathrm{T}$ of the sample can be simply calculated from a measurement of a background signal (B), full-intensity signal (F) and an intensity of light transmitted through a sample (S) as $T=(S-B) /(F-S)$. Such measurement is illustrated in Fig. 3 for a $3 \mathrm{~mm}$ thick UG-11 color filter (Schott). The depicted curves were acquired by using a motorized filter holder with three positions: beam block (background), empty slot (full intensity), and sample (UG-11 filter). We obtained a transmission spectrum which is in accordance with specifications of the measured filter.

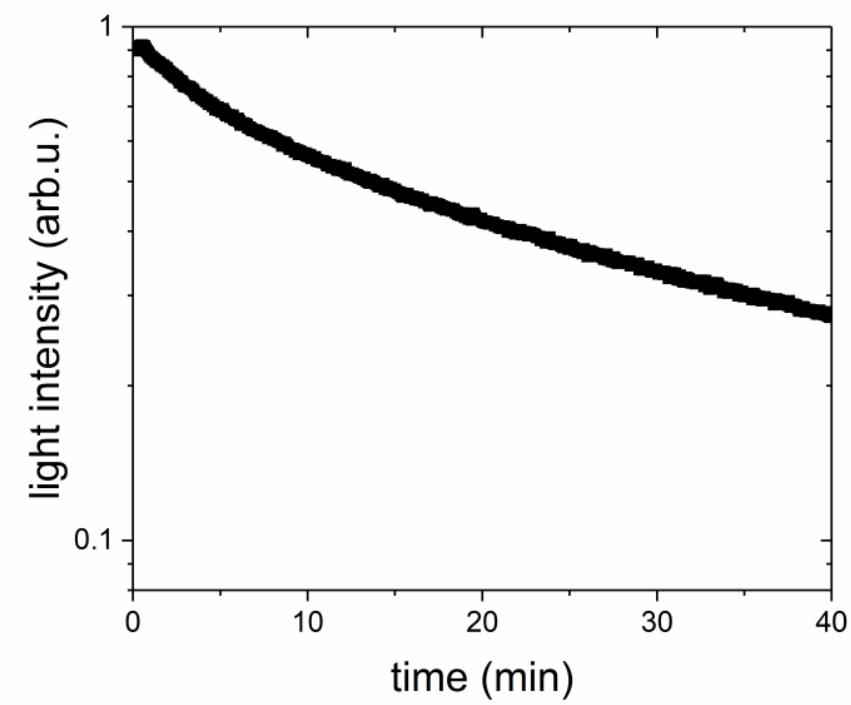

Source: Own

Fig. 4: Decrease in the detected UV light intensity (182 $\mathrm{nm})$ after the nitrogen flushing was terminated 
As we pointed out in the previous section, the experimental setup has to be constantly flushed with nitrogen in order to avoid the VUV light absorption. When the nitrogen flushing of the apparatus is terminated, diffusion of air commences to decrease the light intensity (see Fig. 4). At $182 \mathrm{~nm}$, the light intensity at the PMT detector decreases to 50\% in approx. 15 minutes. This confirms the necessity to constantly keep a slight overpressure of the nitrogen in the system.

\section{$4 \quad$ Future Outlook}

In spite of being able to clearly measure in the VUV spectral range, the presented spectrometer had a limited precision in the spectral region below $180 \mathrm{~nm}$. This was caused by using a home-made UV scintillator based on sodium salicylate layer. In the upgraded version we will employ a commercially-available scintillator (McPherson).

The signal-to-noise ratio can be highly improved by using a synchronous detection (combining an optical chopper and electronic lock-in readout). This will also be implemented in the system upgrade.

Finally, the spacious aluminum box is very convenient for the setup optimization. However, this leads to an extensive consumption of nitrogen. Therefore, in the later stage the setup will be enclosed in a vacuum chamber to avoid the necessity of nitrogen flushing.

\section{Conclusion}

We present construction of a monochromator capable of measuring transmission spectra in the vacuum UV spectral range (above $160 \mathrm{~nm}$ ). Such monochromator can be used to measure transmission spectra of flat VUV optical elements or materials with absorption features of interest in the region (diamond, thin polymer films, etc). We have demonstrated its function of a standard color filter. Furthermore, we propose several steps, which will improve parameters of our setup, so that the parameters will be comparable to commercially available systems.

\section{Acknowledgements}

We gratefully acknowledge the financial support of the Ministry of Education, Youth and Sports of the Czech Republic (Project NPU LO1206).

\section{Literature}

[1] MACLEOD, H. A.: Thin-film optical filters. Taylor\&Fracis Group, 2010. ISBN 978-1420-07303-4.

[2] YU, W. W.; LIANHUA, Q.; WENZHUO, G.; XIAOGANG, P.: Experimental determination of the extinction coefficient of $\mathrm{CdTe}, \mathrm{CdSe}$, and $\mathrm{CdS}$ nanocrystals. Chemistry of Materials. 2003, Vol. 15, Issue 14, pp. 2854-2860. DOI: $\underline{10.1021 / \mathrm{cm} 034081 \mathrm{k}}$

[3] KLIMOV, V. I.: Nanocrystal quantum dots. CRC Press, 2010. ISBN 978-1-420-079265.

[4] TROJÁNEK, F.; ŽÍDEK, K.; DZURŇÁK, B.; KOZÁK, M.; MALÝ, P.: Nonlinear optical properties of nanocrystalline diamond. Optics Express. 2010, Vol. 18, Issue 2, pp. 1349-1357. DOI: $10.1364 /$ OE.18.001349

[5] ZAITSEV, A. M.: Optical properties of diamond: a data handbook. Springer-Verlag, 2013. ISBN 978-3-662-04548-0. 
[6] MORISAWA, Y.; GOTO, T.; IKEHATA, A.; HIGASHI, N.; OZAKI. Y.: FarUltraviolet (FUV) Spectroscopy in the Solid and Liquid States, Principle, Instrumentation, and Application of. In: Encyclopedia of Analytical Chemistry: Applications, Theory and Instrumentation. Chichester, UK: John Wiley \& Sons, Ltd, 2013. DOI: $10.1002 / 9780470027318 . a 9279$

[7] JACKSON, K. A.; SCHROTER, W.: Handbook of semiconductor technology. Wiley-VCH Verlag GmbH, 2000. ISBN 978-3-527-29970-6.

[8] BASTING, D.; MAROWSKY, G.: Excimer laser technology. Springer-Verlag, 2005, ISBN 978-3-540-26667-9.

[9] NAMIOKA, T.: Theory of the Concave Grating. III. Seya-Namioka Monochromator. Journal of the Optical Society of America. 1959, Vol. 49, Issue 10, pp. 951-961. DOI: $\underline{10.1364 / J O S A .49 .000951}$

Ing. Jiří Hlubuček; Ing. Jiří Budasz; Ing. Jan Václavík; RNDr. Karel Žídek, Ph.D. 


\section{KONSTRUKCE TRANSMISNÍHO SPEKTROMETRU PRO VAKUOVOU ULTRAFIALOVOU SPEKTRÁLNÍ OBLAST}

Měření transmise v tzv. vakuové ultrafialové (UV) spektrální oblasti, konkrétně mezi 160 až $190 \mathrm{~nm}$, je důležité pro řadu materiálů (UV optická skla a pokrytí, diamant, tenké polymerní filmy, atd.). Nicméně, nutnost provádět měření ve vakuu a nutnost použití specifických optických elementů určených pro UV záření vede $\mathrm{k}$ tomu, že spektrometry pro oblast vakuového UV světla se vyskytují zř́dka. Zde prezentujeme konstrukci našeho transmisního spektrometru pro vakuovou UV oblast. Je založen na Seya-Namiokově monochromátoru a umožňuje nám určit transmisi planparalelních optických vzorků ve spektrální oblasti od 160 - $600 \mathrm{~nm}$ se spektrálním rozlišením méně než $2 \mathrm{~nm}$. V článku jsou také načrtnuta budoucí vylepšení systému, která výrazně zlepši jeho měřicí parametry.

\section{DIE KONSTRUKTION EINES TRANSMISSIONSSPEKTROMETERS FÜR DEN LUFTLEEREN ULTRAVIOLETTEN SPEKTRALBEREICH}

Die Messung der Transmission im so genannten luftleeren ultravioletten Spektralbereich, konkret zwischen 160 bis $190 \mathrm{~nm}$, ist für eine Reihe von Materialien wichtig (UV-optische Gläser und Abdeckungen, Diamanten, dünne polymere Filme usw.). Nichtsdestoweniger führt die Notwendigkeit der Durchführung von Messungen im Vakuum und der Nutzung spezifischer, für die UV-Strahlung bestimmter optischer Elemente dazu, dass Spektrometer für den Bereich des UV-Lichts im Vakuum nur selten vorkommen. Hier präsentieren wir die Konstruktion unseres Transmissionsspektrometers für den luftleeren UV-Bereich. Er basiert auf Seva-Namioks Monochromator und ermöglicht uns die Bestimmung einer planparallelen Transmission optischer Muster in einem Spektralbereich von 160 bis $600 \mathrm{~nm}$ mit einer spektralen Unterscheidung, die weniger als $2 \mathrm{~nm}$ beträgt. Im Artikel werden auch künftige Verbesserungen des Systems skizziert, welche seine Messparameter bedeutend heraufsetzen.

\section{KONSTRUKCJA SPETROMETRU TRANSMISYJNEGO DLA PRÓŻNIOWEGO ULTRAFIOLETOWEGO ZAKRESU SPEKTRALNEGO}

Pomiar transmisji $\mathrm{w}$ tzw. próżniowym ultrafioletowym zakresie spektralnym, ściślej pomiędzy 160 a $190 \mathrm{~nm}$, jest ważny dla wielu materiałów (szkła optyczne UV, diament, cienkie warstwy polimerowe itd.). Konieczność dokonywania pomiarów w próżni a także niezbędne zastosowanie specyficznych elementów optycznych przeznaczonych do promieniowania UV skutkuje tym, że spektrometry dla zakresu próżniowego promieniowania ultrafioletowego są rzadkością. Prezentujemy konstrukcję naszego spektrometru transmisyjnego dla próżniowego zakresu UV. Oparty jest on na monochromatorze SeyaNamioka. Umożliwia nam określenie w płaszczyznach równoległych transmisji wzorów optycznych w zakresie spektralnym od 160 do $600 \mathrm{~nm}$ z rozdzielczością spektralną poniżej $2 \mathrm{~nm}$. W artykule zasygnalizowano także przyszłe udoskonalenie systemu, które w znacznym stopniu poprawi jego właściwości pomiarowe. 